\title{
Stories of Totalitarianism: Voices Unheard Before- and Now?
}

\author{
LUDMILA VOLNÁ \\ Charles University, Prague \\ Université de Rouen Normandie
}

\begin{abstract}
The stories of those who lost their lives or were subject to different kinds of damage for political reasons during Soviet-governed communist rule in Czechoslovakia (1948-1989), a system not unlike colonisation, have long been unheard. As Václav Havel argues in his essay "Stories and Totalitarianism," due to the institutionalised "rationale of history", Czechoslovakian society experienced the absence of story, indeed a destruction of "the story" altogether. This paper will focus on oral narratives of the so-called Daughters of the Enemy, daughters of long-incarcerated or executed prisoners. What are these women's views of the trauma experienced by the whole culture and do these formerly persecuted individuals now perceive their experiences as a meaningful achievement? Does society provide them with a feeling of satisfaction and/or fulfillment by hearing and/or responding to their voices while successfully coping with the trauma of the culture as a whole, as was the case, for e.g., in South Africa vis-à-vis its former political prisoners? Or is there (still) one kind or other of a (power-motivated) perpetuation of the absence of "the story"? This paper will attempt to address these and other questions within the context of Havel's aforementioned essay.
\end{abstract}

Keywords: totalitarianism, Soviet, communism, Václav Havel, Czechoslovakia, "Daughters of the Enemy"

Colonisation is a significant example of power-based mechanisms operating between cultures. A metropolis, a powerful and privileged centre, interacts with its periphery, the subaltern, the two being typically represented, respectively, by what is generally called the West and the East. The paradigms of such structures can, nevertheless, be studied in a number of other locations and contexts. There are different and varied aspects of how the identity of geographic or geopolitical entities can be traced, conceived or defined. One such example is the so called Soviet bloc, in which the governing of countries like Czechoslovakia, East Germany, Hungary, Poland and others was subject to direct control from Moscow. This resulted in totalitarian state structures being manipulated ideologically by means such as propaganda, in which citizens' freedoms were severely restricted. Other typical features included one-party government, political repression and control over the economy.

The Czech lands, that part of central Europe where, as Milan Kundera remarks, "everyone has always been particularly sensitive to the dangers of Russian might," (Kundera 3) were after WW II confronted with the situation which developed in Europe, "that of Western Europe, that of Eastern Europe, and, most complicated, that of the part of Europe situated geographically in the center - culturally in the West and politically in the East" (Kundera 2). What is generally referred to as a Soviet-style and Soviet-governed communist regime started in Czechoslovakia in 1948. The period when the Communist Party was in power, which ended in 1989, saw hundreds of thousands of people criminalised for political reasons and interned in concentration or work camps. The number of those who died as victims of judicial murders, in prison, or when attempting to flee the country, could well have exceeded six thousand. Some historians claim, that apart from the USSR, the communist regime of Czechoslovakia was one of the most repressive in Europe.

The country experienced the most brutal Soviet-style socialism in the so-called Stalinist period of the 1950s with its abolition of the institution of private ownership, forced collectivisation, and show trials. After a partial release of the grip, which culminated in 1968 during the so-called Prague Spring, came a period called normalisation, a term signifying the return to the pre-reform period, which entailed thorough going political repression, including purges, and the return to ideological conformity. As Milan Otáhal specifies, a stratum of 
Southeast Asian Review of English, Vol. 53, no.1, 2016, pp: 30-38.

the privileged came into existence on the one hand, to which the members of the "nomenklatura" belonged, those who enjoyed special advantages and for whom in fact the laws did not apply, and a class of underprivileged citizens on the other hand, who paid the price for their social engagement in the 1968 events by losing many of their civil rights. The vast majority of the population was to be found somewhere between these two opposite poles (Otáhal 21).

In 2008, nineteen years after the change of regime, an organisation called "Dcery 50. Let", or "Daughters of the Enemy", was founded. The members of this organisation are daughters of former political prisoners who associate with one another with the aim of "educat[ing] younger generations about life under totalitarianism to prevent history from repeating itself in our country or anywhere else" (Daughters). "Daughters" is a non-governmental non-profit organisation whose members find that it is often difficult to do more than to associate with and accompany each other, in Dori Laub's words, on "a journey the survivor cannot traverse or return from alone" (Laub 59). Even just telling their own stories is a difficult task because they must first "testify to an absence, to an event that has not yet come into existence, in spite of the overwhelming and compelling nature of the reality of its occurrence" (Laub 57). Yet as much as they can the Daughters tell their stories in individual conversations with people and in seminars for teachers and discussions with young people at schools. The audiovisual testimonies of some of their family histories have been recorded in collaboration with the Institute of Contemporary History of the Czech Academy of Sciences, Centre for Oral History, and the Film and TV School of Academy of Performing Arts, and broadcast on Czech television. Their stories as well as the news and actions related to them have also been published on the association's website.

The members of the organisation were children in the 1950s and remember well what happened to their parents and to themselves during that period. Refraining from supporting the official Communist Partyoutlined political system in different ways, for example by insisting on a different party's or another group's independent policy or simply by being independent entrepreneurs, the parents were charged with treason, subversion or espionage and labeled "enemies of the state". The children faced multiple problems: the absence of their parents, who experienced seriously damaged health, both physical and mental, when they came back (if they did); the loss of their homes; and their difficulty in seeking a livelihood because the adults who survived had often lost their jobs. But apart from this, their own lives were marked by ostracism and the interdiction to study. Whole families were thus broken apart and forced to struggle in many respects.

The Daughters' reminiscences reveal a high degree of suffering at the time when these events were happening. They mention themselves and their siblings as young children missing their parents, being considered second-rate citizens, experiencing fear of authorities, fear of living, weeping and overall sadness, feelings of wrongdoing and injustice, tension and frustration, feelings of insecurity and betrayal (because of denunciators), feelings of rejection, exclusion and loneliness. This sense of exclusion and loneliness particularly permeate their stories: not only were the incarcerated parents not permitted to speak about their prison life, but they were actually incapable of telling their stories; thus, neither they nor the children were capable of meaningfully conveying their painful experiences at the time. The trauma pervaded the entire family. There was silence.

Václav Havel, writer, dissident and, after the change of the political regime in Czechoslovakia, the country's president, theorised about the political structures of totalitarian regimes during the normalisation period. In his essay "Stories and Totalitarianism" (1987), he at first contemplates the period of the 1950s, mentioning the concentration camps, show trials and executions and all the other horrors, as well as the fanatical fervour of the builders of the "new society". Of the dark period of the 1950s, he argues that "no one could have said that nothing was happening, or that the age did not have its stories" (Havel 1987). The 
Daughters' and their parents' experiences were part of that period: however, the regime did its best to make sure that these so-called enemies of the state were made examples of to the rest of society. That was the regime's grand or overarching story. On the other hand, as has been mentioned, the stories of these individuals remained unheard as most of them were unable to speak: they were treated as not having the right to their own story; it was solely the regime that had the right to tell the story, and this was projected as the only story worth telling.

If Havel first argues that in the 1950s the story, albeit the story of the regime, undeniably played a role, he next refers to the 1970s and 1980s as a period characterized by an "advanced totalitarian system," in which dullness and emptiness induced a sentiment of an absence of the passage of time, having an undeniable impact on the story:

The interplay of "historical laws," "social groups" and "relations of production" gradually expelled from history the very thing that gives human life, time and thus also history itself a structure: the story. [...] When the story is destroyed, the feeling of historicity disappears as well. I remember the early seventies in Czechoslovakia as a time when something like a "cessation of history" took place; public life seemed to lose its structure, its impulse, its direction, its tension, its rhythm, its mystery. I can't remember what happened when, or what made one year different from another. (Havel 1987)

The situation in the 1970s and 1980s, the period of normalisation, is then, as Havel emphasises, different from that of the 1950s. It is this period that becomes the focus of his essay. Havel holds that during this period the story simply ceased to exist:

It would seem that the absolute, "classical" death of which one reads in stories (and which for all the terrors it holds is still mysteriously able to impart meaning to human life) has been replaced here by another kind of death: the slow, secretive, bloodless, never quite-absolute, yet horrifyingly ever-present death of non-action, non-story, non-life, and non-time; the collectively deadening, or more precisely, anesthetising, process of social and historical nihilisation. (Havel 1987)

Elements that make a story a story are eliminated while the "nihilisation annuls death as such, and thus annuls life as such: the life of an individual becomes the dull and uniform functioning of a component in a large machine, and his death is merely something that puts him out of commission" (Havel 1987).

After the 1968 Soviet-led invasion of Czechoslovakia what Havel calls the "samopohyb" ("self-drive movement"), the "blind automatism which drives the system" (Havel 63) and the "all-encompassing grasp" of the totalitarian ideology (Havel 1987), together with the totally uniform and ritualised way of life, brought with it a substantial change in society: an "unobservable inner destruction" (Havel 1987) which manifested itself in a "brutal castration of man's humanity and will or urge to think and act independently" (Havel 2027). There is apathy, restlessness, vague feelings of being threatened, stress and depression, oppression, anxiety, uncertainty, insecurity. This self-alienation results in the loss of moral principles, there occurs disinterestedness in values surpassing the immediately personal, loss of interest in others, spiritual passivity, resignation, hypocrisy, cowardice and even aggressiveness (Havel 20-27).

If, as Havel points out, "the story took with it into the kingdom of unmeaning its two essential ingredients: uniqueness and ambiguity" (Havel 1987), then "history began to lose its human content. [...]The uniqueness of the human creature became a mere embellishment on the laws of history, and the tension and thrill in real events were dismissed as accidental and therefore unworthy of the attention of scholarship" (Havel 1987). 
Southeast Asian Review of English, Vol. 53, no.1, 2016, pp: 30-38.

Petr Fleischman, a historian and philosopher, relates history-writing directly to the individual and subjectivity: according to him it is a "process of discovering of that humanity in oneself which interconnects me with the subjectivities of those on whom I am supposed to give an account. An account on the past with which we wish to cope" (Fleischman).

Here, story and history are directly related to each other. Havel and Fleischmann express a common idea, i.e. that understanding and empathy, the concern for human individuals and their subjective stories, should be the point of departure for historians and their work, contrary to the totalitarian, rigorously programmed, propaganda-controlled so-called historical actions (events), that are devoid of real concern for people because they disrespect and even straightforwardly trample upon human rights, needs, wishes and freedoms. Each person's story is unique and ambiguous and they all together offer a still more complex mélange of apparently ambiguous features, so typical of the human condition, and of life and reality as such.

The fall of the Czechoslovak Soviet-controlled totalitarian system in 1989 brought with it changes that required the new government(s) to come to terms with the wrongs of the previous regime; part of the process was the restoration of historicity with what nourishes it, the story. As we have seen, the 1970s and 1980s, the decades preceding the change of regime, were deprived of those precise qualities which would have made it possible to listen to the stories of others, of those who had the most to tell of the sense of belonging, of interest in the individual other, of courage and honesty, of the sense of being firmly and securely rooted in the world and having an active attitude with regard to society and the environment. The sterile and oppressive atmosphere of those decades, offering no space for stories to be heard, could not naturally change overnight.

The sense of belonging or being integrated in society and the interconnecting of subjectivities seems to play a crucial role in the way the painful events are viewed by those concerned, and that is true both for the time when these events were happening and afterwards. In their study "Oppression, Resistance and Imprisonment: A Montage of Different but Similar Stories in Two Countries” Jan K. Coetzee and Otakar Hulec compare two groups of former political prisoners - those of the apartheid regime in South Africa and those once imprisoned in Czechoslovakia. With regard to coping with trauma, within each group the perception of past experiences at the time when they occurred is similar to how they are currently perceived, but crucially these two groups' perceptions differ from each other.

In South Africa, these prisoners, whose stand was supported by the majority of society, were perceived as political prisoners, a category of its own, and kept apart from the criminals. This enabled them to keep their integrity both as individuals and as a group. This was quite the opposite to the experience of the Czechoslovak prisoners: "they looked at us as something much worse than these murderers," says one of them. "They were saying that on our hands there was blood of their mothers and I don't know whatever. So, you see, we were really class enemies" (Coetzee and Hulec 85). The Czech political prisoners experienced isolation, abandonment, being left on their own. "The authoritarianism practised in South Africa was less all-pervading, and in the end, less effective than the full-fledged totalitarianism of the Eastern Bloc countries" (Coetzee and Hulec 91).

The pervasiveness of the totalitarian regime, which brought with it all the social phenomena Havel mentions into the post-1989 period, as quoted above, appears to be responsible for the country's inability to deal with the trauma of the past. It is true that the political prisoners were indeed released and the central role of the Communist Party abolished. The repressive provisions of the penal code were abrogated, the oppressive organs were dissolved, and the Acts on Judicial and Extra-Judicial Rehabilitations were passed (Act No. 119/1990 Sb. and Act No. 87/1991 Sb. - see David and Choi 346). Some other laws were passed, among them those proclaiming the communist regime as illegitimate and its policies and related actions as criminal, and later on, those authorising the government to mitigate the wrongs committed both towards those active in the 
Southeast Asian Review of English, Vol. 53, no.1, 2016, pp: 30-38.

resistance movement as well as towards the victims. In 1995, the Office for the Documentation and Investigation of Communist Crimes was established.

In spite of this effort to cope with the past, there were many disappointments even within its scope. The attempts to recuperate stolen properties were beset by difficulties in establishing accurate ownership data, as well as other problems. The Act enabling access to the secret police files came too late as the secret police had been non-existent for seven years, more than enough time for a large number of files to be destroyed or redacted. The compensation given, if any, was hardly more than a symbolic gesture towards victims, who had led lives of poverty in the past and continued to do so in the newly established present. The Institute for the Study of the Totalitarian Regimes, which was established in 2007, has during the whole period of its existence been criticised as controversial for its lack of professional faculty, as has its research for its politically motivated points of departure.

No truth or reconciliation commission has been established in the Czech Republic as was the case in South Africa. Besides the secret police files, it is the media that have become the main source of information on what actually happened. The radio- and newspaper-transmitted series called "Stories of the 20th Century" is the most consequential, and a project by Post Bellum: Pamět' národa (Memory of Nations), a nongovernmental association founded in 2001.

It is also quite difficult to see the mechanisms Roman David and Susanne Y. P. Choi mention are at work in the Czech Republic while dealing with the perpetrators. In their words, it is:

[the p] unishment [that] signifies the new government's recognition of past wrongdoings and its willingness to take action to address them. The absence of punishment, on the contrary, fuels new resentment and frustrations, often associated with a lack of forgiveness and reconciliation. [...] the absence of punishment signifies the absence of any stimulus for perpetrators to realise their guilt. Without being punished, perpetrators are viewed as remorseless, perpetuating past divisions. (David and Choi 361, emphasis in original)

Punishment has been significantly lacking in the Czech Republic. First, many collaborators' names do not appear in the lustration lists and thus the question of their appearing before justice does not even arise. The prosecution of those responsible for politically-motivated judicial murders or torture was often either stopped as statute-barred, or resulted in a merely symbolic penalty, or else took more than ten years to arrange, during which time most of the accused often died.

For example, Karel Vaš, prosecutor in the 1950s, proposed the death penalty in about a hundred political processes and was thus directly responsible also for the judicial murder of Heliodor Píka, hero of WW II. He was accused of the latter crime after 1990 but in 2002 the prosecution was stopped because the act became statute-barred. "I did not hurt anybody on purpose. But I did not permit any dirty business in my surroundings," is how Vaš, called "the judge hanger" by political prisoners, expresses his stance (Pamět' národa: "Karel Vaš”). Alois Grebeníček, investigator of the secret police, accused in 1997 of torturing prisoners in the 1950s using medieval torture methods as well as those of the Gestapo, successfully avoided trial till his death in 2003.

Another significant example is Ludmila Brožová-Polednová, an attorney in the 1950s. She was responsible for the judicial murders of social democrat Milada Horáková and three others as prosecutor, and after years of discussions was sentenced to prison, but was granted the President's pardon after eighteen months. In her words, the process in which she participated as prosecutor was just, even if "too strict;" she had to obey orders and to act accordingly (Brožová-Polednová). 
These are just three of the most widely-known examples of perpetrators whose actions during the 1950s were considered by the justice system. Brožová-Polednová was the only one to be sentenced, while the identities of the vast majority of persecutors of both the 1950s and the normalisation period have never become known to the broader public and/or brought to court. As referred to by David and Choi, the absence of a real willingness to take action on the part of the Czechoslovak and Czech governments to deal with the wrongdoings means there is no real recognition of these wrongs. Apathy, spiritual passivity, resignation, hypocrisy, cowardice and disinterest, so typical of the 1970s and 1980s' normalisation years, is thus perpetuated even after the fall of the system in which they developed. The perpetrators' stories do not meet the stories of their victims and thus history remains to some extent as ahistorical as before.

How is the present situation viewed by the Daughters? First, they are all grateful that they have come together within this association, even if at the beginning their meetings were still marked by the "fear of being listened to - and of listening to themselves" (Laub 58), reminding us thus of similar anxieties faced by their parents. Their testimonies speak of the lack of justice as regards the perpetrators and of insufficient information for the general public, and the widespread disinterest in what had happened. While together with one another, they enjoy the sense of belonging that they miss in society at large. They lament that they still feel excluded and not fully part of post-1989 society. As Coetzee and Hulec summarise, "[t]here is undoubtedly a tendency to incorporate current conditions when evaluating past experiences. People's interpretations of past experiences of long-term imprisonment are tinted by their current political and material conditions" (Coetzee and Hulec 92). To quote some of the Daughters:

It still hurts. - Justice should be done. - People need to be in touch, together, there must be sharing. - I considered it my duty to join the Daughters' project to tell the story and to thank everybody who wants to listen. It must be talked about. People do not want to hear about it, they are bored; one cannot do anything about the old generation. (Ludmila Zouharová)

[...] it took time to be able to talk. - The truth about what was happening should have been revealed (earlier, now it's too late). I don't understand; but in fact I do - the judges were the same people as before. - People are losing their memory. (Hana Tížková)

What is important is not to forget the past, to know about it. I believe that many people here do not know what was happening here. (Jarmila Bílková)

We will be haunted all our lives. - After the political change we expected justice - they did not even apologize. I cannot forgive that regime. It's frustrating to hear people praise the former regime. - I am irritated by their [the communists'] utterances, or when someone says, yes, it was like that during communism; people are perhaps losing their memory. (Eliška Vlčková)

I am telling my story while discussing with young people. - The worst thing is that no justice has been done. This Brožová, it's terrible. - I want the perpetrators to admit and tell their story. (Věra Pytlíčková)

Even now the perpetrators can be threatening. - People do not want to believe what happened; some people will never accept it, they are not able to. They still cherish memories of the old order when they were taken care of. - Today is a traumatising experience: former secret police officials occupy high positions even now. (Dagmar Stachová) 
Jana Švehlová, who founded the Daughters association, is a psychologist as well as the child of political prisoners. As she puts it, "[F] or the Czech and Slovak children of former political prisoners, not to be silenced by the silence of others can help to heal their emotional wounds" (Švehlová, emphasis added). The Daughters' feelings expressed above point to the fact that not only has a large part of the population not recognised the events that constitute the stories of the Daughters, but also sometimes the truth of what happened is outright denied. The absence of story as theorised by Havel is thus perpetuated even in the present. Not only do the Daughters have to face the silence of others but their prevailing sentiment is that dullness, emptiness, passivity and lack of interest, the features of the normalisation period described by Havel, prevent people even in the present from being willing to listen to or even believe what was happening.

To conclude, the former Czechoslovak prisoners have been incapable of "recontextualising their traumatic experiences into purposive life stories" as the former South-African prisoners were able to do:

Success in the struggle created an ability [in the former Robben Islanders] to integrate into a coherent life story the hardship and humiliation of their incarceration with the accomplishment of the victory. [...] In the case of the former Czechoslovakia, those who told us their stories were not convinced that the political structure in their country had changed dramatically. Although the present situation was different from that of the past, they did not regard the change as being a victory for their own struggle. On the contrary: a degree of isolation and alienation from the prevailing social and political structure is reflected in their life stories. The injustices and trauma that they had experienced remained strong when they looked back on their lives. (Coetzee and Hulec 92, 93)

Past divisions are perpetuated (David and Choi 361, see also above) and the bystanders of the past have become the bystanders of the present (See Laub 81). In the words of Antonín Huvar, a former political prisoner and Catholic priest, "[i]f there is a guilt that is not dealt with, the curse remains. The nation is cursed twice if they do not deal with those who were killed. Schools, courts, judges, even the constitutional court. We are the last ones who cry for this because the majority of us have already died" (Antonín Huvar qtd in David and Choi 363, emphasis added).

\section{Note}

1. This essay is a revised version of the paper presented at the 17th Triennial ACLALS Conference in Stellenbosch, South Africa, 11-15 July 2016, with the theme of "Stories that Float from Afar: The Idea of Postcolonial Culture - Inclusions and Exclusions". The author is grateful to ERIAC (Équipe de Recherche Interdisciplinaire sur les Aires Culturelles), Université de Rouen Normandie for its financial support.

\section{Works Cited}

Bílková, Jarmila and Ústav pro soudobé dějiny ČAV, Centrum orální historie. [Institute of Contemporary History of the Czech Academy of Sciences, Centre for Oral History]. "Conversation." Dcery čs. politických vězňu 50. let 20. století. [Daughters of the Enemy.] Collection of conversations conducted by Film Faculty students-directors. Directed by Petr Hatle, under the supervision of director Helena Třeštíková, 2008.

Brožová-Polednová, Ludmila. Interview by Radim Vaculík. "I did not feel well at Horáková’s execution." 
Southeast Asian Review of English, Vol. 53, no.1, 2016, pp: 30-38.

Novinky.cz, 10 Sept. 2008, http://www.novinky.cz/domaci/149236-ludmila-brozova-polednova-pripoprave-horakove-mi-bylo-spatne.html. Accessed 24 May. 2012.

Coetzee, Jan K. and Otakar Hulec. "Oppression, Resistance and Imprisonment: a Montage of Different but Similar Stories in Two Countries." Trauma: Life Stories of Survivors, edited by Rogers, Kim Lacy, Selma Leydesdorff and Graham Dawson, Transaction Publishers, 1994, pp. 80-94.

David, Roman and Susanne Y.P. Choi. "Forgiveness and Transitional Justice in the Czech Republic." The Journal of Conflict Resolution, vol.50, no.3, 2006, pp: 339-367.

Dcery. http://www.dcery.cz/?rid=10\&nbsp. Accessed 12 Oct. 2010.

Fleischmann, Petr. "Minulost jako filosofický problém: Politici, historici a totality.” Britské listy. 26 May. 2010, http://www.blisty.cz/art/52694.html. Accessed 21 May. 2012.

Havel, Václav. "Moc bezmocných." [“The Power of the Powerless." Written in 1978.] O lidskou identitu. [On Human Identity]. (1984 London) Rozmluvy: Praha, 1990, pp55-133.

Havel, Václav. "Dopis Gustávu Husákovi.” [“An Open Letter to Dr. Husak, General Secretary of the Czechoslovak Communist Party.”] 1975. O lidskou identitu. [On Human Identity]. (1984 London) Rozmluvy: Praha 1990. 19-49. First published in English in Encounter (Sept 1975).

Havel, Václav. "Př́běh a totalita." ["Stories and Totalitarianism.”] (April 1987) Written for the underground cultural journal Jednou nohou (Revolver Review) and dedicated to Ladislav Hejdánek on his sixtieth birthday. In English, it appeared in Index on Censorship, no. 3 (March 1988) and, in a slightly different version, in The Idler, Toronto, no. 18 (July-August 1988). Translation by Paul Wilson. http://www.vaclavhavel.cz/showtrans.php?cat=clanky\&val=77_clanky.html\&typ=HTML

Kundera, Milan. “UN OCCIDENT KIDNAPPÉ: ou la tragédie de l'Europe centrale.” Le Débat, vol.5, no.7, 1983, pp:3-23.

Laub, Dori. “An Event Without a Witness: Truth, Testimony and Survival.” Testimony: Crises of Witnessing in Literature, Psychoanalysis and History, edited by Shoshana Felman and Dori Laub, Routledge, 1992, pp. 75-92.

Otáhal, Milan. Opozice, moc, společnost 1969-1989. Příspěvek k dějinám “normalizace.” [Oposition, Power, and Society 1969-1989. Contribution Towards the History of "Normalization.”] Praha: Ústav pro soudobé dějiny/Maxdorf, 1994. Translation of the quotation is mine.

Pamět' národa. [Post Bellum: Memory of Nations.] "Karel Vaš.” http://www.pametnaroda.cz/.

Pytlíčková, Věra and Ústav pro soudobé dějiny ČAV, Centrum orální historie. [Institute of Contemporary History of the Czech Academy of Sciences, Centre for Oral History]. "Conversation." Dcery čs. politických věznnu 50. let 20. století. [Daughters of the Enemy.] Collection of conversations conducted 
Southeast Asian Review of English, Vol. 53, no.1, 2016, pp: 30-38.

by Film Faculty students-directors. Direction Petr Hatle, under the supervision of director Helena Třeštíková. 2008.

Stachová, Dagmar and Ústav pro soudobé dějiny ČAV, Centrum orální historie. [Institute of Contemporary History of the Czech Academy of Sciences, Centre for Oral History]. "Conversation." Dcery čs. politických vězňu 50. let 20. století. [Daughters of the Enemy.] Collection of conversations conducted by Film Faculty students-directors. Direction Petr Hatle, under the supervision of director Helena Třeštíková. 2008.

Švehlová, Jana. Dcery čs. politických vězñu 50. let 20. století. [Daughters of the Enemy.] http://www.enemysdaughters.com/?nid=753\&lang=en, Accessed 12 Oct. 2010.

Tížková, Hana and Ústav pro soudobé dějiny ČAV, Centrum orální historie. [Institute of Contemporary History of the Czech Academy of Sciences, Centre for Oral History]. "Conversation." Dcery čs. politických vězňu 50. let 20. století. [Daughters of the Enemy.] Collection of conversations conducted by Film Faculty students-directors. Direction Petr Hatle, under the supervision of director Helena Třeštíková. 2008.

Ústav pro soudobé dějiny, Centrum orální historie. Dcery čs. politických vězňů 50. let 20. století. [Daughters of the Enemy.] Collection of conversations conducted by Film Faculty students-directors. Direction Petr Hatle, under the supervision of director Helena Třeštíková. 2008. All the translations of quotations from Daughters are mine.

Vlčková, Eliška and Ústav pro soudobé dějiny ČAV, Centrum orální historie. [Institute of Contemporary History of the Czech Academy of Sciences, Centre for Oral History]. "Conversation." Dcery čs. politických vězňu 50. let 20. století. [Daughters of the Enemy.] Collection of conversations conducted by Film Faculty students-directors. Direction Petr Hatle, under the supervision of director Helena Třeštíková. 2008.

Zouharová, Ludmila and Ústav pro soudobé dějiny ČAV, Centrum orální historie. [Institute of Contemporary History of the Czech Academy of Sciences, Centre for Oral History]. "Conversation." Dcery čs. politických vězňu 50. let 20. století. [Daughters of the Enemy.] Collection of conversations conducted by Film Faculty students-directors. Direction Petr Hatle, under the supervision of director Helena Třeštíková. 2008. 